\title{
Influence of products and principles of sharia bank on customer decision with perception as intervening variable in Bank Jambi Syariah
}

\author{
Dahmiri \\ Department of Management, Faculty of Economics and Business, Universitas \\ Jambi, Indonesia
}

Correspondence author email:dahmiri@unja.ac.id

\begin{abstract}
This study aims to analyze the influence of sharia bank products and the principles of sharia banks on customer decisions with perception as an intervening variable in Bank Jambi Syariah. Questionnaires were distributed to 301 customers. Analytical tool used is Structural Equation Modeling (SEM) analysis. The results indicate that sharia bank products, principles of sharia banks, and customer perceptions significantly influence both partially and simultaneously on the decision of Bank Jambi Syariah customers. Indirectly, products and principles of sharia bank significantly influence Bank Jambi Syariah customer decisions through customer perception. The dominant variable influencing customer decision is the principles of sharia bank. The originality of the model is reflected on the addition of an intervening variable, showing that there is a greater impact on the customer decision by including perception compared to the impact without including customer perception.
\end{abstract}

Keywords: Bank, Customer decisions, Syariah

JEL Classification: G41, G51, M31

\section{INTRODUCTION}

Advancements in various sectors of live never stop in line with the increasingly complex human needs and desires. Banking industry development is no less rapid with developments in other sectors with its new findings in effort to meet the life necessities.

The presence of Islamic Banks or Sharia Banks is a new thing in the modern economic system, where its emergence is in line with intense efforts in supporting Islamic economics carried out by Islamic economists. They believe that Islamic banks will be able to replace and improve conventional economic system which is based on interest (Antonio, 2012).

In Indonesia, the issuance of Law Number 21 of 2008 concerning Sharia Banking has an impact on the rapid development of the sharia banking industry because this law becomes a strong legal foundation in encouraging the development of sharia banking. The average growth of assets of sharia banks is generally higher than conventional banks, which is $18.81 \%$ in 2012-2018 (Jayani, 2019).

The development of sharia banks in Jambi Province showed a significant increase each year when it is compared to the growth of sharia banks at national level. Based on Bank Indonesia's data in 2018, in terms of assets, the development of sharia banks reached 6.40 percent of the total commercial banks in Jambi. This number is higher than the national share which is 4.75 percent (Jayani, 2019). 
Bank Jambi Syariah is one of the sharia banks in Jambi Province and a business unit of Bank Jambi. Its development of the number of customers from year to year continues to increase for all products. In 2015, the number of customers was 3,446 and it increased in 2018 to 122,324 (Bank Jambi Syariah, 2019).

Customers' decisions on bank services and products are influenced by various factors including the type of products, the bank principles, and perceptions of the bank. Studies examining the effects of bank products and bank principles on customer perceptions and decisions to use bank products have been carried out both on conventional banks and sharia banks. However, study that combines products, principles of sharia banks, customer perceptions and decisions has never been done on a global scale, especially on Bank Jambi Syariah.

The selection of Bank Jambi Syariah as the study's object is due to the phenomenon of gap is more common in Bank Jambi Syariah compared to Bank Syariah Nasional (National Sharia Bank). In this respect, the model of the influence of products and principles of sharia bank on customer decisions with perception as an intervening variable in Bank Jambi Syariah becomes an interesting topic to be studied.

\section{LITERATURE REVIEW}

\section{Sharia bank products}

The principles of Islamic banking are based on: (Kasmir, 2010)

a. Justice. It can be seen from the reward system that is based on profit sharing and profit margins mutually agreed between the customer and the bank.

b. Partnership. Islamic banks regard the position of investor customers (depositors) and users of funds are equal as business partners.

c. Transparency. It can be seen through bank financial reports transparently an ongoing basis and customers can find out the level of security of funds and bank management.

d. Universality. In its operations, the bank does not differentiate customers based on their ethnic, religion, race, and religious groups in society in accordance with Islamic principles as rahmatal lil 'alamiin.

Based on the principle, sharia banking products are divided into three parts: the collection of funds (funding), the channeling of funds (financing), and a product involving service (service) (Karim, 2004)

a. Funding

Funding in Sharia Bank can be in the form of demand deposit, saving deposit, and time deposit. Demand deposit is a deposit that can be withdrawn at any time using cheque, bilyet giro, other payment instruction, or by overbooking. Saving deposit is a deposit that can be withdrawn based on specified requirements agreed in advance, but cannot be withdrawn using cheque, bilyet giro, and or other similar instruments. Based on Law Number 10 of 1998, time deposit is a deposit of fund that may only be withdrawn after a specified term based on the agreement between the customer and the bank.

\section{b. Financing}

Financing to customers is divided into four categories: 1) sale and purchase transaction in the form of Murabahah, Salam, and Istishna'; 2) leasing transaction in the form of Ijarah, based on the transfer of benefits. While in sale and purchase transaction the object of transaction is goods, the object of transaction in ijarah is service; 3) Financing based on profit sharing (syirkah), in the form of Musyarakah and Mudharabah; 4) Financing with contracts, including hiwalah (transfer of a debt), rahn 
(pledge or mortgage), qardh (lending and borrowing of funds), wakalah (representative/agency), and kafalah (bank guarantee).

c. Service

There are two service products in Islamic banking, namely: a) Sharf or foreign currency exchange. Banks can earn profit from the rate margin in the event of different currencies, however the transaction must be conducted by using the exchange rate applicable at the time of transaction; b) Ijarah or leasing is a contract on using the benefits or services in return for compensation (Muhammad, 2004).

\section{Relationship of products, principles, perceptions, and customer decisions}

Perception is the process of selecting, organizing, and interpreting information inputs to create meaningful picture of the world Kotler (2016). Gibson, Ivancevich, Donelly, \& Konopaske, (2012) stated that there are two factors influencing perception: 1) Internal factors: factors in the individuals including physiology, similar needs, attention, desires, and emotions; 2) External factors: characteristics of the environment. These factors could change people's perspective on the world around them and affect people's respond to feel and receive it. External factors influencing perception are: the size and placement of the object or stimulus, the colour of the object, the intensity and strength of the stimulus, and the motion and contrast of the stimulus.

Furthermore, decision is the choice of an action from two or more alternative choices. A consumer has various alternative choices before deciding to make, choose, and determine the purchase Schiffman \& Wisenblit (2019). Pride and Ferrell (2010) divided factors influencing consumer decision into: 1) Personal factors are unique factors of an individual. Various factors influence purchasing decisions. Personal factors are classified into three, namely demographic factor, involvement factor, and situational factor; 2) Psychological factors exist in an individual that determines partially that person's behavior, affecting the behavior as a consumer, i.e. motives, perceptions, knowledge, and personality and abilities.

The interrelationship between products, principles of Sharia/Islamic banks, customer perceptions, and customer decisions has been carried out by researchers at different places and times. Theories and previous studies have shown a strong relationship between service products and customer decisions. The better the quality of the service, the higher chance the customer's decision to buy is. Studies on the influence of sharia banking products on customer decisions found that sharia banking products indeed have an influence on the decision to become customers of sharia banks (Chotimah, 2014; Susanto, Waluyo \& Listyorini, 2012; Sumantri, 2014; Doraisamy, 2011; Rustam, Bibi, Zaman, Rustam \& Haq, 2011; Bashir, 2013).

Principles of Islamic banks are very good and accepted well by consumers. The better these principles are applied, the more it will influence the customer's decision to use the services of a sharia bank. Studies on the influence of Islamic banking principles on sharia bank customer decisions found that there is an influence of these principles on the decision to become sharia bank customers (Kurniawati, 2014; Maisur \& Shabri, 2015; Ahmad \& Humayoun, 2011; Haque, Lone \& Thakur, 2017; Akacem \& Gilliam, 2002).

Customer perceptions of Islamic banks have a strong relationship with customer decisions. The better the customer perception of the bank, the higher chance the customer decides to become a customer of the bank. Studies on the influence of perceptions on the decision to become a sharia bank customer found that perceptions of sharia banks influence the customer decision (Rahmawaty, 2014; Astuti \& Mustikawati, 
2013; Fada \& Wabekwa, 2012; Ahmad \& Haron, 2002; Ritonga, 2013; Bick, Brown \& Abratt, 2004).

The difference of this research with previous studies can be seen from several aspects, among others, the object of research. Studies on conventional banks has been carried out frequently both on a global and regional scale, while there is a limited research on Islamic bank/Sharia bank on a local scale, especially in Jambi Province. In terms of research variables, there are also differences with previous studies. There has not been previous research that combines products, principles, customer perceptions, and customer decisions in one model. The difference lies on the analytical method. Previous studies used linear regression analysis tools, for example in the studies of Chotimah, 2014; Susanto, Waluyo \& Listyorini, 2012; Doraisamy, Shanmugam \& Raman, 2011; Bashir, 2013; Kurniawati, 2014; Maisur \& Shabri, 2015; Rahmawaty, 2014; Astuti \& Mustikawati, 2013. Meanwhile some other studies used the average method as conducted by Rustam, Bibi, Zaman, Rustam, \& Haq, 2011; Fada \& Wabekwa, 2012; Ahmad \& Haron, 2002; Bick, Brown \& Abratt, 2004. This research uses Structural Equation Modeling (SEM) as the analysis tool which had not been widely used in previous studies.

\section{METHODS}

\section{Data types and sources}

Data used for this study are primary data and secondary data. Questionnaires to respondents, Bank Jambi Syariah customers, were distributed to obtain primary data directly from the object under study. Secondary data were from literature studies.

\section{Population and Sample}

The study population was all customers of Bank Jambi Syariah, in total of 122,324 people (Bank Jambi Syariah, 2019). Samples were selected from Bank Jambi Syariah customers by simple random sampling, where each customer has the same opportunity to become a respondent. According to Sevilla (2007), Slovin formula can be used to determine the sample size of the population, i.e.

$$
n=\frac{N}{1+N e^{2}}=\frac{122,324}{1+122,324\left(0.05^{2}\right)}=301
$$

Whereas :

$\mathrm{n}:$ Number of Samples

$\mathrm{N}$ : Number of Population

$\mathrm{e}^{2}$ : Margin of error $(5 \%)$

\section{Data processing method}

Data collection instrument for this study is a structured questioner. Attributes under study refer to 5 point Likert scale (1-5). Validity, reliability, and normality tests were conducted in order to obtain validity and reliability of the questionnaire.

Model and hypothesis testing is using Structural Equation Modelling (SEM) analysis with AMOS. Hypotheses of the developed research model are tested by SEM techniques with a two-step approach (Brown and Peterson, 1994; Baldauf, David, and Nigel, 2001).

The first stage is an assessment of the measurement model and then the model is used in the second stage when assessing the structural model (Ferdinand, 2014). The reasoning for this approach is that an accurate representation of the realibity of 
indicators can be accomplished well in two stages in order to avoid the interaction of the measurement model and the structural model. In the first stage, a qualitative analysis was carried out. Meanwhile a quantitative approach was used in the second stage to analyze the data, using Structural Equation Modeling (SEM). To examine the influences simultaneously, both direct and indirect influences between variables, the study used SPSS.

Table 1. Operational definition of research variables

\begin{tabular}{|c|c|c|c|c|}
\hline Variables & Definition & Indicators & Scale & Item \\
\hline \multirow{3}{*}{$\begin{array}{l}\text { Sharia Bank } \\
\text { Products }(\xi 1)\end{array}$} & \multirow{3}{*}{$\begin{array}{l}\text { Sharia Banking products are divided into } \\
\text { three parts, including the collection of } \\
\text { funds (funding), the channeling of funds } \\
\text { (financing), and a product involving } \\
\text { service (service) (Karim, 2004) }\end{array}$} & Funding & Interval & 1 \\
\hline & & Financing & Interval & 2 \\
\hline & & Service & Interval & 3 \\
\hline \multirow{4}{*}{$\begin{array}{l}\text { Principles of } \\
\text { Sharia Bank } \\
(\xi 2)\end{array}$} & \multirow{4}{*}{$\begin{array}{l}\text { The bank services provided in sharia bank } \\
\text { are in accordance with sharia principles } \\
\text { and Islamic law (Kasmir, 2002) }\end{array}$} & Justice & Interval & 4 \\
\hline & & Partnership & Interval & 5 \\
\hline & & Transparency & Interval & 6 \\
\hline & & Universality & Interval & 7 \\
\hline \multirow{2}{*}{$\begin{array}{l}\text { Perception } \\
(\eta 1)\end{array}$} & \multirow{2}{*}{$\begin{array}{l}\text { Perception is the process of selecting, } \\
\text { organizing, and interpreting information } \\
\text { inputs to create meaningful picture of the } \\
\text { world (Kotler, 2016) }\end{array}$} & Internal factors & Interval & 8 \\
\hline & & External factors & Interval & 9 \\
\hline \multirow{2}{*}{$\begin{array}{l}\text { Costumer } \\
\text { Decision } \\
(\eta 2)\end{array}$} & \multirow{2}{*}{$\begin{array}{l}\text { Purchasing decision is the selection of an } \\
\text { action from two or more alternative } \\
\text { choices before deciding on a purchase } \\
\text { (Schiffman, Leon, Kanuk, Lazar and } \\
\text { Joseph, 2013) }\end{array}$} & Personal factors & Interval & 10 \\
\hline & & $\begin{array}{l}\text { Psychological } \\
\text { factors }\end{array}$ & Interval & 11 \\
\hline
\end{tabular}

Source: Modified from various sources, 2019.

\section{RESULTS AND DISCUSSION}

\section{Results}

Customer responses to the Islamic/Sharia banking products (X1) which consist of three indicators, namely funding, financing, and service have the average score of 3.57. It means that the customers feel that sharia banking products are good. The customer responses to the principles of Islamic banks (X2) which consist of four indicators: justice, partnership, transparency, and universality have the average score of 3.62. It means that the customers feel that the principles of Islamic/sharia banks are good.

Customer responses to the perception (Y1) which consists of two indicators, namely internal factors and external factors, obtained an average score of 3.39 or "good enough". Customer responses to customer decisions (Y2) which consist of two indicators, personal factors and psychological factors, have an average score of 3.6 or "good".

Statements on the questionnaire are all valid and show a positive direction because the results of validity test showed Corrected Item Total Correlation greater than 0.3. Reliability test through Spearman Brown correlation obtained Cronbach's Alpha score above 0.6, indicating that all statement items are reliable. Normality test of the data shows the skewness ratio $=-0.302 / 0.423=-0.724$, while kurtosis ratio $=-0.004 / 0.826$ $=-0.005$. Because the skewness ratio and kurtosis ratio are between -2 to +2 , it can be concluded that the data distribution is normal. 
Table 2. Item-total statistics

\begin{tabular}{|c|c|c|c|c|c|}
\hline & $\begin{array}{l}\text { Scale Mean if } \\
\text { Item Deleted }\end{array}$ & $\begin{array}{l}\text { Scale Variance if } \\
\text { Item Deleted }\end{array}$ & $\begin{array}{l}\text { Corrected Item- } \\
\text { Total Correlation }\end{array}$ & $\begin{array}{l}\text { Cronbach's } \\
\text { Alpha if } \\
\text { Deleted }\end{array}$ & Item \\
\hline VAR00001 & 93.4333 & 131.426 & .630 & & .928 \\
\hline VAR00002 & 93.5000 & 135.707 & .624 & & .928 \\
\hline VAR00003 & 93.6000 & 133.697 & .645 & & .928 \\
\hline VAR00004 & 93.4333 & 140.530 & .313 & & .932 \\
\hline VAR00005 & 93.5000 & 137.086 & .470 & & .930 \\
\hline VAR00006 & 93.9000 & 127.541 & .666 & & .928 \\
\hline VAR00007 & 92.7333 & 137.099 & .566 & & .929 \\
\hline VAR00008 & 93.1667 & 135.661 & .475 & & .931 \\
\hline VAR00009 & 93.2333 & 140.530 & .370 & & .931 \\
\hline VAR00010 & 93.6333 & 139.826 & .389 & & .931 \\
\hline VAR00011 & 93.2667 & 135.444 & .529 & & .930 \\
\hline
\end{tabular}

Table 3. Reliability Statistics

\begin{tabular}{clcc}
\hline No & \multicolumn{1}{c}{ Variable } & Cronbach's Alpha & N of Items \\
\hline 1 & Sharia Banking Products (X1) & .932 & 3 \\
2 & Principles of Sharia Bank (X2) & .954 & 4 \\
3 & Customer Perception (Y1) & .880 & 2 \\
4 & Customer Decision (Y2) & .878 & 2 \\
\hline
\end{tabular}

To do a thorough hypothesis testing, it is necessary to present its full Structural Equation Model. It can be seen in the following Figure.

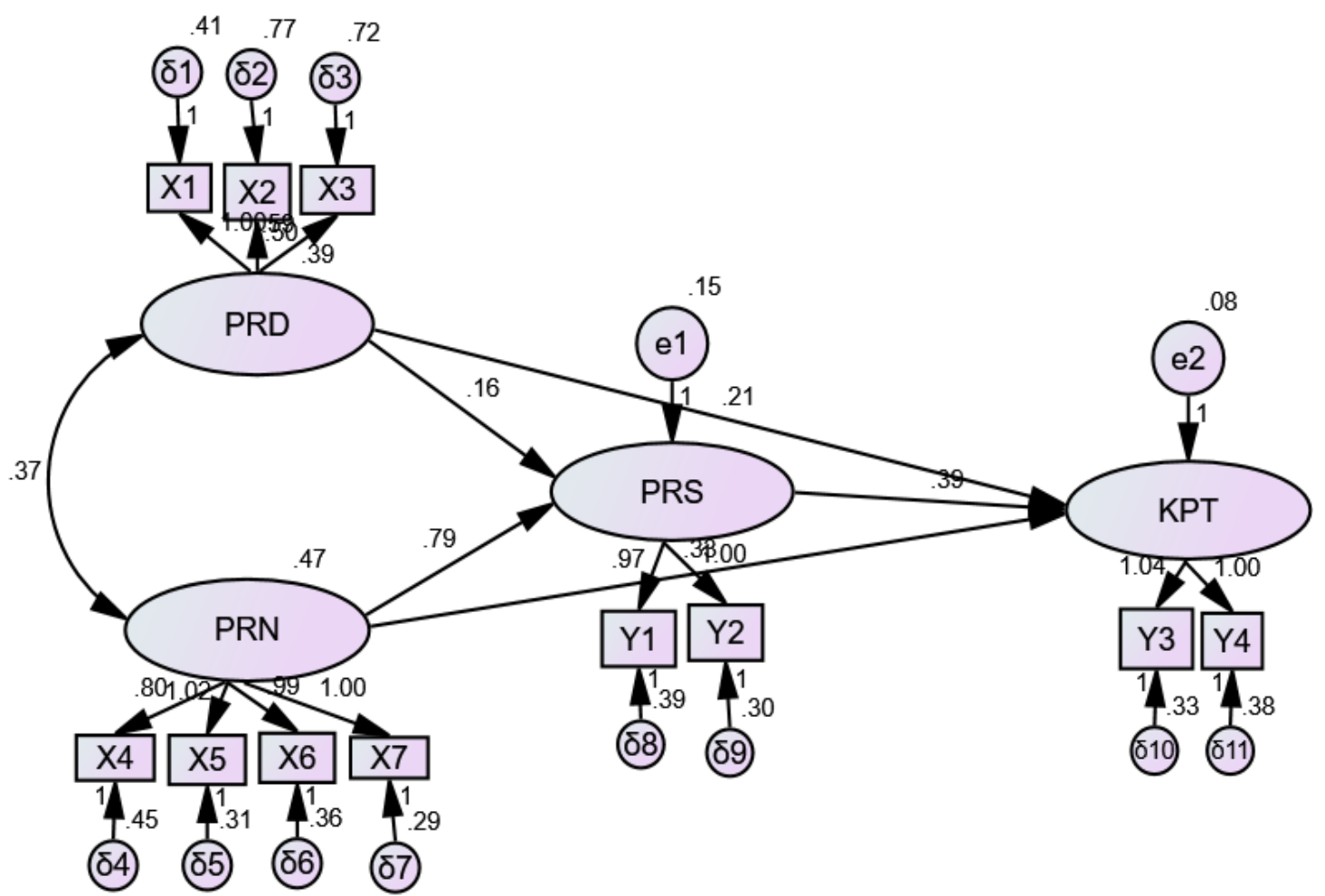

Figure 1. Structural Equation Model 

indices.

Goodness-of-fit test is carried out to see the GFI, AGFI, TLI, CFI, and RMSEA

Table 4. Goodness-of-fit indices

\begin{tabular}{lccc}
\hline \multicolumn{1}{c}{ Goodness of fit Index } & Cut-off Value & Model Result & Conclusion \\
\hline Degree of freedom, DF & 0,08 & 147 & \\
RMSEA & 0,90 & 0.072 & Goodness of Fit \\
GFI & 0,90 & 0.908 & Goodness of Fit \\
AGFI & 2,00 & 0.912 & Goodness of Fit \\
CMIN/DF & 0,90 & 1.832 & Goodness of Fit \\
TLI & 0,90 & 0.909 & Goodness of Fit \\
CFI & & 0.922 & Goodness of Fit \\
\hline
\end{tabular}

Source: Data processed (2019)

From Table 4, it shows that the RMSEA statistic is 0.072 , a value lower than the recommended 0.08, the GFI statistic is 0.908 and greater than 0.90 , the AGFI statistic is 0.912 and greater than 0.90 , the CMIN/DF statistic is 1.832 and less than 2.00 , the TLI statistic is 0.909 and greater than 0.90 and the CFI statistic is 0.922 and greater than 0.90 . The results obtained in the analysis indicated an appropriate overall fit of the measurement model. According to Arbuckle and Wothke (2000), the best criteria to consider a good fit of the model is that the CMIN/DF statistic is below the maximum recommended value of 2 and the RMSEA statistic is below the maximum recommended value of 0.08 so it signifies a good model fit for all indices and the proposed model can be analyzed.

The results of significance tests of products and principles of sharia bank on customer decisions with perception as an intervening variable both partially and simultaneously are:

1. Hypothesis 1

$\mathrm{H} 1$ is accepted because the value $(\mathrm{P})<0.05$. The conclusion is that sharia banking products have a significant influence on perception.

2. Hypothesis 2

$\mathrm{H} 2$ is accepted because $(\mathrm{P})<0.05$. The conclusion is that the principles of sharia bank have a significant effect on perception.

3. Hypothesis 3

$\mathrm{H} 3$ is accepted because $(\mathrm{P})<0.05$. The conclusion is that sharia banking products have a significant influence on customer decisions.

4. Hypothesis 4

H4 is accepted because $(\mathrm{P})<0.01$. The conclusion is that the principles of sharia banks have a significant effect on the customer decisions.

5. Hypothesis 5

Simultaneously, the products and the principles of sharia banking influence perception $(121.532>1.96)$

6. Hypothesis 6

Simultaneously, the products and the principles of sharia banking influence the customer decisions $(122.242>1.96)$

7. Hypothesis 7 
H7 is accepted because $(\mathrm{P})<0.05$, that is $0.004<0.05$. The conclusion is that the perception has a significant effect on the customer decisions.

8. Hypothesis 8

Simultaneously, the sharia banking products, the principle of sharia banks, and the perception have an influence on the customer decisions (112.445 > 1.96)

The direct relationship occurs between exogenous latent variables (products, principles) with endogenous intervening latent variable (perception) and endogenous latent variable (decision). The following table presents results of direct effects between exogenous and endogenous latent variables.

Table 5. Direct effects among research variables

\begin{tabular}{lccc}
\hline & \multirow{2}{*}{ Direct Effects } & \multicolumn{2}{c}{ Endogenous Variables } \\
\cline { 3 - 4 } & & Perception & Decision \\
\hline Exogenous & Products & 0.160 & 0.210 \\
Variables & Principles & 0.790 & 0.380 \\
& Perception & 0.000 & 0.390 \\
\hline
\end{tabular}

As Table 5 shows, the strongest direct effect on customer perception is exercised by the principles of sharia banks of 0.79 . It indicates that principles as a latent variable contributes greatly in influencing perceptions. If the principle of sharia bank is improved by one unit, then the customer perception will increase by 0.79 . The strongest direct effect on decision is exercised by perception of 0.39 . If the perception is improved by one unit, then the customer decision will increase by 0.39 .

Indirect relationship between exogenous latent variables (products, principles) and endogenous intervening latent variable (perception) and endogenous latent variable (decision) is as Table 6.

Table 6. Indirect effects among research variables

\begin{tabular}{lccc}
\hline \multirow{2}{*}{ Indirect Effects } & \multicolumn{2}{c}{ Endogenous Variables } \\
\cline { 2 - 4 } & Products & Perception & Decision \\
\hline Exogenous & Principles & 0,000 & 0,1250 \\
& Perception & 0,000 & 0,1670 \\
& & 0,000 & 0,000 \\
\hline
\end{tabular}

The results in Table 6 show the indirect effects of exogenous latent variables on endogenous latent variables. The strongest indirect effect on decision is the principles of sharia banks of 0.167. It indicates that the principles of sharia bank as a latent variable contribute largely in influencing customer decisions, or every increase in the principles of sharia bank will result on the increase in customer decision by 0.167 .

The direct relationships occur between exogenous latent variables (products, principles) with endogenous intervening latent variable (perception) and endogenous latent variable (decision). The following table presents the results of total effects:

Table 7. Total effects among research variables

\begin{tabular}{llcc}
\hline \multirow{2}{*}{ Total Effects } & \multicolumn{2}{c}{ Endogenous Variables } \\
\cline { 2 - 4 } Exogenous Variables & Products & 0,160 & Decision \\
& Principles & 0,790 & 0,267 \\
& Perception & 0,000 & 0,635 \\
\end{tabular}


The total effects of exogenous latent variables on endogenous latent variables are shown in Table 7. The strongest total effect on perception is the principles of sharia banks, equal to 0.790 . This means that each time the principles of sharia banks are improved then the customer perceptions will increase by 0.790 . The strongest total effect on the decision is the principles of sharia banks of 0.635 . This means that the principles of sharia banks as a latent variable have a large contribution in influencing customer decisions, or each time the principles are improved by one unit, the customer decisions will increase by 0.635 .

\section{Discussion}

Decisions of Bank Jambi Syariah customer can be influenced by sharia banking products, the principles of sharia banks, and customer perceptions. After conducting literature review, it was found that there was no research that included customer perception as an intervening variable. The addition of customer perception as a variable is a novelty in this research model. The results of testing found that customer perception as intervening variable can influence customer decisions for Bank Jambi Syariah and the value for customer decisions is higher with customer perception, compared to without customer perception as variable. The $\mathrm{R}$ square value obtained is $58.6>52.1$.

The results of this study have similarities in terms of the variables used and support previous studies on the influence of Islamic bank products on customer decisions, including studies of Chotimah, 2014; Susanto, Waluyo \& Listyorini, 2012; Sumantri, 2014; Doraisamy, Shanmugam \& Raman, 2011; Rustam, Bibi, Zaman, Rustam, \& Haq, 2011; Bashir, 2013. This study is also in line with the results of previous studies that sharia bank principles influence customer decisions, including research conducted by Kurniawati, 2014; Maisur \& Shabri, 2015; Ahmad \& Humayoun, 2011; Haque, Lone, \& Thakur, 2017; Akacem \& Gilliam, 2002. Customer perceptions have a significant effect on customer decisions, the results of this study are in line with previous studies by Rahmawaty, 2014; Astuti \& Mustikawati, 2013; Fada \& Wabekwa, 2012; Ahmad \& Haron, 2002; Ritonga, 2013; Bick, Brown \& Abratt, 2004.

\section{CONLUSIONS AND RECOMMENDATIONS}

\section{Conclusions}

The sharia banking products, the principles of sharia bank and the customer perceptions partially have influenced significantly the decision of Bank Jambi Syariah customers. Simultaneously, sharia banking products, principles of sharia banks, and customer perceptions influence the decision of Bank Jambi Syariah customers.

The indirect effect between sharia bank products on the customer decision through customer perception as an intervening variable has a significant effect. In terms of indirect effect between the principles of sharia bank on the customer decision through customer perception as an intervening variable resulted on significant effect on the decision of Bank Jambi Syariah customers.

Variable that has a dominant influence on customer decision is the principles of sharia banks. The novelty of this study is the addition of customer perception as 
intervening variable. The test results show that the effect on the decision of Bank Jambi Syariah is even greater.

\section{Recommendations}

Based on the research findings, there are several policy implications in accordance with priorities as input for management, in order to improve customer decisions, including: 1) There should be more varied and more attractive products of sharia bank; 2) Improving the application of Islamic bank principles, especially the principle of justice to all customers; 3) Increasing customer perception, among others, by improving services, bank environment, and bank facilities.

This study chose sharia bank as the research subject and the next researchers are advised to conduct similar study on commercial banks to find out similarities and differences between two groups of banks and also to give contributions to the development of science. Future studies are suggested to examine other variables such as service quality, marketing characteristics, bank characteristics, promotions, and others.

\section{REFERENCES}

Ahmad, A., \& Humayoun, A.A. (2011). Islamic banking and prohibition of Riba/interest. African Journal of Business Management, 5(5), 1763-1767.

Ahmad, N., \& Haron, S. (2002). Perceptions of Malaysian corporate customers towards Islamic banking products and services. International Journal of Islamic Financial Services, 3(4), 13-29.

Akacem, M., \& Gilliam, L. (2002). Principles of Islamic banking: Debt versus equity financing. Middle East Policy, 9(1), 124.

Antonio, S. (2012). Bank Syariah Dari Teori Ke Praktek. Jakarta: Gema Insani Press.

Arbuckle, J.L. \& Worthke, W. (2000). Amos 7.0 User's Guide. USA: Development Corporation.

Astuti, T., \& Mustikawati, R.I. (2013). Pengaruh Persepsi Nasabah Tentang Tingkat Suku Bunga, Promosi dan Kualitas Pelayanan terhadap Minat Menabung Nasabah. Nominal, Barometer Riset Akuntansi dan Manajemen, 2(1), 182198.

Bank Jambi Syariah. (2019). Perkembangan Nasabah Bank Jambi Syariah. Jambi: Bank Jambi Syariah

Bick, G., Beric Brown, A., \& Abratt, R. (2004). Customer perceptions of the value delivered by retail banks in South Africa. International Journal of Bank Marketing, 22(5), 300-318.

Baldauf, A., David, W.C. \& Nigel, F.P. 2001. Examining the Consequences of Sales Management Control Strategies in European Field Sales Organizations, International. Marketing Review, 18 (5):474 - 508.

Bashir, M.S. (2013). Analysis of customer satisfaction with the Islamic banking sector: case of Brunei Darussalam. Asian Journal of Business and Management Sciences, 2(10), 38-50.

Brown, S. \& Peterson, R. A. (1994). The Effect of Effort on Sales Performance and Job Satisfaction. Journal of Marketing, 58 (April):70-80. 
Chotimah, C. (2014). Pengaruh Produk, Pelayanan, Promosi Dan Lokasi Terhadap Masyarakat Memilih Bank Syariah Di Surakarta(Unpublished Doctoral dissertation). Universitas Muhammadiyah Surakarta, Surakarta.

Doraisamy, B., Shanmugam, A., \& Raman, R. (2011). A Study on Consumers'perferences Of Islamic Banking Products And Services In Sungai Petani. Academic Research International, 1(3), 290- 302.

Fada, K.A., \& Wabekwa, B. (2012). People's perception towards Islamic banking: a field work study in Gombe Local Government Area, Nigeria'. International Journal of Business, Humanities and Technology, 2(7), 121-131.

Ferdinand, A. (2014). Metode Penelitian Manajemen. Semarang: Badan Penerbit Universitas Diponegoro

Gibson, J.L., Ivancevich, J.M., Donelly, J.H. \& Konopaske, R. (2012). Organizational Behavior, Structure, Processes, Fourteenth Edition. New York: McGraw-Hill.

Haque, I., Lone, F.A., \& Thakur, G. (2017). Islamic banking in India: what more needed?. Journal of Islamic Economics, Banking and Finance, 5(3), 75-86.

Jayani, D.H. (2019). Berapa Aset Perbankan Syariah dan Konvensional? Available at: https://databoks.katadata.co.id/datapublish/2019/09/20/berapa-aset-perbankansyariah-dan-konvensional

Karim, A., (2004). Bank Islam Analisis Fiqih Dan Keuangan-Edisi Keempat. Jakarta: PT. Raja Grafindo Persada. .

Kasmir. (2010). Dasar-dasar Perbankan. Jakarta: Rajawali Pers.

Kasmir. (2002). Bank dan Lembaga Keuangan Lainnya. Jakarta: Raja Grafindo Persada.

Kotler, P. \& Keller K. L. (2016). Marketing Managemen. Pearson Education,Inc.

Kurniawati, E.T. (2014). Analisis Pengaruh Profitabilitas Sistem Bagi Hasil dan Kualitas Layanan Bank terhadap Minat Nasabah Berinvestasi (Studi Kasus Pada Bank Muammalat Cabang Malang). Jurnal Humanity, 7(2). 46-55.

Maisur, M. A., \& Shabri, M. (2015). Pengaruh Prinsip Bagi Hasil, Tingkat Pendapatan, Religiusitas dan Kualitas Pelayanan Terhadap Keputusan Menabung Nasabah pada Bank Syariah di Banda Aceh. Jurnal Administrasi Akuntansi: Program Pascasarjana Unsyiah, 4(2). 1-8.

Muhammad. (2004). Teknik Penghitungan Bagi Hasil dan Profit Margin Pada Bank Syariah. Yogyakarta: UII Press.

Pride, W.M. \& Ferrel, O.C. (2010). Marketing. Sourth Western International Edition.

Rahmawaty, A. (2014). Pengaruh persepsi tentang bank syariah terhadap minat menggunakan produk di BNI Syariah Semarang. Jurnal Addin, 8(1). 1-28.

Rustam, S., Bibi, S., Zaman, K., Rustam, A., \& Haq, Z.U. (2011). Perceptions of corporate customers towards Islamic banking products and services in Pakistan. The Romanian Economic Journal, 41(4), 107-123.

Ritonga, H. A. H. D. H. (2013). Persepsi Etnis China Terhadap Perbankan Syariah Di Kota Medan. Jurnal Ekonomi dan Keuangan, 1(2). 41-55.

Schiffman, L.G \& Wisenblit, J.L. (2013). Consumer Behavior. Pearson

Sumantri, B. (2014). Pengaruh Kualitas Pelayanan Dan Produk Pembiayaan Terhadap Minat Dan Keputusan Menjadi Nasabah Di Bank Syariah. Jurnal Economia, 10(2), 141-147. 
Susanto, M. D. A., Waluyo, H. D., \& Listyorini, S. (2012). Pengaruh Produk Tabungan Dan Kualitas Pelayanan Terhadap Keputusan Menabung Pada KJKS BMT Binna Ummat Sejahtera Kec. Lasem. Jurnal Ilmu Administrasi Bisnis, 1(2), 177-186.

(C) 2020 by the authors. Licensee JPPD, Indonesia. This article is an open access article distributed under the terms and conditions of the Creative Commons Attribution (CC BY) license (http://creativecommons.org/licenses/by/4.0/). 